\title{
PENGARUH BIOKSIDA PENGOKSIDASI TERHADAP PERTUMBUHAN MIKROORGANISME PADA AIR PENDINGIN SEKUNDER RSG-GAS
}

\author{
DiYAH ERLINA LESTARI, SETYO BUDI UTOMO \\ Pusat Reaktor Serba Guna-BATAN \\ Kawasan Puspiptek Serpong, Tangerang Selatan 15310,Banten \\ Telp.021.7560908,Faks 7560573
}

\begin{abstract}
Abstrak
PENGARUH BIOKSIDA PENGOKSIDASI TERHADAP PERTUMBUHAN MIKROORGANISME PADA AIR PENDINGIN SEKUNDER RSG-GAS. Sistem Pendingin sekunder RSG-GAS merupakan sistem air pendingin sirkulasi ulang terbuka. Salah satu permasalahan yang timbul pada sistem air pendingin resirkulasi terbuka adalah pertumbuhan mikroorganisme. Untuk mengendalikan pertumbuhan mikroorganisme pada sistem pendingin sekunder RSG-GAS ditambahkan bahan kimia bioksida pengoksidasi dan dilakukan pemantauan terhadap pertumbuhan mikroorganisme pada air sistem pendingin.sekunder Pemantauan pertumbuhan mikroorganisme dilakukan dengan jalan penentuan jumlah total bakteri pada sistem pendingin sekunder dengan menggunakan dipslide test. Dari hasil pemantauan menunjukan bahwa pertumbuhan mikroorganisme pada air pendingin sekunder lebih cepat pertumbuhannya pada saat sistem pendingin sekunder tidak beroperasi dan akan mengalami penurunan pertumbuhannya setelah penambahan bioksida pengoksidasi,.
\end{abstract}

Kata kunci: pertumbuhan mikroorganisme

\begin{abstract}
EFFECT OF OXIDIZING BIOXIDES TO THE MICROORGANISM GROWTH AT RSG-GAS SECONDARY COOLING WATER .The RSG-GAS secondary cooling system is open recirculation cooling water. One of the problem at the recirculation open cooling water system is the microorganism growth. To control of the microorganism growth at RSG-GAS secondary cooling system carried out by addition oxidizing biocides chemical and monitoring of the microorganism growth in secondary cooling water. Monitoring of the microorganism growth carried out by determine total count of bacteri in secondary cooling water system with Dipslides Test. From the monitoring result showed that at the secondary cooling system shutdown was the microorganism growth at secondary cooling water system growth faster .and than decrease growth after addition of the oxidizing biocides.
\end{abstract}

Keyword: microorganism growth 


\section{PENDAHULUAN}

Sistem pendingin sekunder reaktor G.A.SIWABESSY merupakan sistem air pendingin resirkulasi terbuka, yang dalam artian pendinginan berhubungan langsung dengan sirkulasi udara luar. Sistem pendingin terbuka akan memungkinkan udara luar dari lingkungan sekitarnya berinteraksi langsung dengan air pendingin sekunder pada cooling tower. Salah satu permasalahan yang timbul pada sistem air pendingin resirkulasi terbuka adalah pertumbuhan mikroorganisme. Keberadaan mikroorganisme dalam air serta dalam jaringan pipa distribusi akan menimbulkan lendir yang merupakan sekresi dari mikroorganisme. Lendir ini akan mengikat padatan yang tersuspensi dan terakumulasi pada persimpangan pipa distribusi sehingga akan mengurangi debit air dalam sistem pendingin dan effesiensi panas dari alat penukar panas. Disamping itu adanya mikroorganisme dengan tingkat kelekatan yang tinggi pada pipa akan menimbulkan korosi dan kerak pada pipa sistem pendingin Hal ini akan mempengaruhi kinerja sistem pendingin sekunder Reaktor Serba Guna G.A Siwabessy.

Di RSG-GAS untuk mengendalikan pertumbuhan mikroorganisme dilakukan dengan memakai bahan pengontrol pertumbuhan mikroorganisme. Sebagai bahan pengontrol pertumbuhan mikroorganisme pada sistem pendingin sekunder RSG-GAS digunakan inhibitor oxidizing biocides (bioksida pengoksidasi) dan non oxidizing biocides (bioksida bukan pengoksidasi) ${ }^{[1]}$. Inhibitor bioksida pengoksidasi yang digunakan akan bekerja secara langsung membunuh mikroorganisme sedangkan inhibitor bioksida bukan pengoksidasi berperan untuk menekan pertumbuhan mikroorganisme dalam sistem pendingin sekunder ${ }^{[1]}$. Penambahan bioksida pengoksidasi pada sistem pendingin sekunder dilakukan dua hari sekali pada saat sistem pendingin sekunder beroperasi. sedangkan penambahan inhibitor bioksida bukan pengoksidasi dilakukan pada awal dan akhir pengoperasian sistem pendingin sekunder. Sebagai parameter kontrol penambahan inhibitor bioksida pengoksidasi dilakukan pengukuran kandungan klorine dalam air pendingin sekunder dan untuk mengetahui efektifitas terhadap perlakuan pada pengendalian pertumbuhan mikroorganisme pada sistem pendingin sekunder RSG-GAS perlu adanya pemantauan terhadap pertumbuhan mikroorganisme pada sistem air pendingin. Pemantauan pertumbuhan mikroorganisme dilakukan dengan jalan penentuan total bakteri pada sistem pendingin sekunder dengan menggunakan dipslide test. 


\section{TEORI}

Mikroorganisme merupakan jasad hidup yang mempunyai ukuran sangat kecil (biasanya kurang dari $1 \mathrm{~mm}$ ) sehingga untuk mengamatinya diperlukan alat bantuan. Mikroorganisme seringkali bersel tunggal (uniselular) meskipun beberapa protista bersel tunggal masih terlihat oleh mata telanjang dan ada beberapa spesies multisel tidak terlihat mata telanjang ${ }^{[2]}$. Ilmu yang mempelajari mikroorganisme disebut mikrobiologi. Orang yang bekerja di bidang ini disebut mikrobiolog. Kebanyakan orang beranggapan bahwa yang dapat dianggap mikroorganisme adalah semua organisme sangat kecil yang dapat dibiakkan dalam cawan petri atau inkubator di dalam laboratorium dan mampu memperbanyak diri secara mitosis.

Setiap sel tunggal mikroorganisme memiliki kemampuan untuk melangsungkan aktivitas kehidupan antara lain dapat dapat mengalami pertumbuhan, menghasilkan energi dan bereproduksi dengan sendirinya. Mikroorganisme memiliki fleksibilitas metabolisme yang tinggi karena mikroorganisme ini harus mempunyai kemampuan menyesuaikan diri yang besar sehingga apabila ada interaksi yang tinggi dengan lingkungan menyebabkan terjadinya konversi zat yang tinggi pula. Akan tetapi karena ukurannya yang kecil, maka tidak ada tempat untuk menyimpan enzim-enzim yang telah dihasilkan. Dengan demikian enzim yang tidak diperlukan tidak akan disimpan dalam bentuk persediaan.enzim-enzim tertentu yang diperlukan untuk perngolahan bahan makanan akan diproduksi bila bahan makanan tersebut sudah ada. Mikroorganisme ini juga tidak memerlukan tempat yang besar, mudah ditumbuhkan dalam media buatan, dan tingkat pembiakannya relative cepat ${ }^{[3]}$. Oleh karena aktivitasnya tersebut, maka setiap mikroorganisme memiliki peranan dalam kehidupan, baik yang merugikan maupun yang menguntungkan.

Pada sistem pendingin keberadaan mikroorganisme akan menyebabkan terjadinya slime (lendir) yang merupakan akumulasi kotoran lumpur lunak dari kotoran mikroorganisme. Umumnya mikroorganisme membentuk koloni pada titik yang rendah kecepatan alirannya atau di daerah yang rindang . oleh karena itu alat penukar panas dan menara pendingin mudah terakumulasi kotoran lumpur lunak dari kotoran mikroorganisme.

\section{Faktor Yang Menyebabkan Pertumbuhan Mikroorganisme ${ }^{[4]}$}

1. Zat makanan bagi mikroorganisme

Mikroorganisme memerlukan berbagai jenis makanan untuk pertumbuhanya seperti senyawa karbon, phosphat dan lain-lain. Mikroorganisme mengambil energi serta bahan makanan untuk pertumbuhan mereka dengan cara yang tidak sama. Ada tiga unsur 
dimana bahan-bahan makanan masuk ke dalam sistem air pendingin yaitu air tambahan, udara dan kebocoran proses.

2. Temperatur air

Pengaruh temperatur terhadap pertumbuhan mikroorganisme tergantung pada jenis mikroorganisme, karena tiap mikroorganisme mempunyai temperatur optimum untuk pertumbuhan berbeda-beda. Dalam hal ini temperatur optimum adalah antara $30^{\circ} \mathrm{C}-40^{\circ} \mathrm{C}$.

3. $\mathrm{pH}$

Umumnya bakteri tumbuh dengan baik pada rentang $\mathrm{pH}$ netral sampai basa. $\mathrm{pH}$ optimum pertumbuhan bakteri adalah pada rentang $\mathrm{pH}$ antara 69.

4. Oksigen terlarut

Bakteri aerob dan jamur memperoleh energi yang diperlukan untuk pertumbuhannya dari reaksi dekomposisi oksida zat organik dengan oksigen terlarut. Sistem air pendingin sirkulasi ulang terbuka menyediakan kondisi-kondisi yang optimum karena oksigen terlarut yang diperlukan tersedia dalam jumlah yang cukup banyak pada air pendingin.

5. Sinar matahari

Di antara mikroorganisme yang tumbuh pada sistem air pendingin hanya lumut yang memanfaatkan sinar matahari. Sedangkan banyak mikroorganisme lain tidak memerlukan sinar matahari untuk pertumbuhannya.

6. Jumlah bakteri

Frekuensi timbulnya masalah lumut rendah apabila bakteri kurang dari $10^{3}$ bakeri $/ \mathrm{mL}$, dan frekuensi naik apabila jumlah melebihi $10^{6}$ bakteri/mL.

7. Kekeruhan

Kekeruhan yang lebih rendah atau lebih jernih, akan lebih baik bagi pencegahan lumut dan akumulasi lumpur.

8. Volume lumut

Volume lumut adalah sejumlah $\mathrm{mL}$ zat yang diperoleh dari penjaringan 1 $\mathrm{m}^{3}$ air pendingin menggunakan kasa plankton. Dalam suatu sistem pendingin apabila volume lumut lebih besar dari $10 \mathrm{~mL} / \mathrm{m}^{3}$, terjadinya masa lumut akan meningkat.

9. Tingkat kelekatan lumut

Tingkat adhesi lumut akan merupakan indeks yang efektif untuk adhesi lumut pada air pendingin. Tingkat adhesi lumut adalah fungsi absorbansi.

10. Laju alir air

Lumpur akan berakumulasi dengan cepat di daerah yang laju alirnya rendah. Lumut jarang terakumulasi apabila laju alir di dalam pipa lebih dari $0,5 \mathrm{~m} / \mathrm{dt}$ atau laju alir horizontal pada ruang pemisah lebih besar dari $0,1 \mathrm{~m} / \mathrm{dt}$. 


\section{Penanganan Masalah Lumut/ Mikroorganisme}

Cara mengatasi tumbuhnya lumut dan mikroorganisme pada pendingin sekunder adalah sebagai berikut:

1. Pencegahan kontaminasi nutrisi dan padatan tersuspensi pada air pendingin. Untuk mencegah agar sekecil mungkin kontaminasi nutrisi dan padatan tersuspensi yang berasal dari air make-up, dilakukan pra pengolahan seperti penyaringan.

2. Pemakaian bahan pengontrol lumut. Fungsi dari bahan pengontrol lumut diklasifikasikan atas sterilisasi. Karena setiap bahan pengontrol lumut mempunyai mekanisme kerja yang berbeda, maka apabila penanggulangan lumut dilakukan, kondisi deposit lumut harus dipelajari supaya dapat memilih bahan kimia yang sesuai

\section{Sterilisasi}

Sterilisasi adalah suatu perawatan untuk merendahkan potensi pelekatan mikroorganisme dalam sistem air pendingin dengan jalan pembunuhan mikroorganisme.

Bahan kimia yang mempunyai efek sterilisasi adalah senyawa klor, senyawa organik, nitrogen-sulfur dan lain-lain. Mekanisme kerja bahanbahan kimia ini diperkirakan sebagai berikut, bahan kimia ini mempunyai reaktivitas yang tinggi terhadap radikal SH sistein (komponen protein dalam mikroorganisme), dan membunuh mikroorganisme dengan jalan melumpuhkan enzim (bagian yang aktif) radikal $\mathrm{SH}$, atau membunuh mikroorganisme dengan daya oksidasi dari bahan kimia tersebut.

Secara umum, klorinasi digunakan untuk sterilisasi karena efektif dan murah. Namun, karena klor bersifat korosif terhadap metal, maka konsentrasi sisa klor (residual chlorine) dalam air pendingin harus dikontrol meksimum 1 $\operatorname{ppm}\left(\mathrm{Cl}_{2}\right)$.

1. Peredaman pertumbuhan mikroorganisme . Ini adalah perawatan dengan menurunkan kecepatan pertumbuhan lumut dengan jalan meredam pertumbuhan mikroorganisme dalam sistem pendingin air sekunder. Mekanisme kerja bahan kimia yang digunakan hampir sama dengan mekanisme kerja biocide-boicide lainnya, hanya penggunaannya yang berbeda. Pada perawatan ini perlu dipertahankan pemakaian bahan kimia secara kontinu / dalam waktu relatif lama walaupun konsentrasi kecil. Sedangkan biocide lainnya adalah sebaliknya. Bahan kimia yang cocok untuk perawatan secara biostatik adalah senyawa organik nitrogen-sulfur dan senyawa-senyawa amina.

2. Pencegahan pelekatan

3. Getah lender yang diproduksi mikroorganisme bertalian dengan pelekatan mikroorganisme pada permukaan padatan. Dalam pencegahan 
pelekatan lumut, bahan kimia bereaksi dengan getah lender dan kemudian menetralisasinya, sehingga daya pelekatan mikroorganisme diturunkan atau dilemahkan. Bahan kimia yang mempunyai efek seperti ini adalah senyawa garam ammonium kwartener, senyawa bromine dan lain-lain.

4. Pengikisan lumut

5. Perawatan ini adalah mengikis lumut yang melekat pada sistem pendingin dengan bahan-bahan kimia. Bahan kimia yang mempunyai efek mengikis adalah senyawa klor, proksida, senyawa amina dan lainlain. Mekanisme kerja bahan-bahan kimia ini menurunkan daya pelekatan lumut dengan jalan denaturasi getah lender dan membentuk gelembung-gelembung, akibat reaksi bahan kimia dengan lumut, sehingga lumut secara alami terkikis. Dengan demikian setelah penambahan bahan kimia, dengan menaikkan kecepatan aliran air akan meningkatkan efek pengikisan.

6. Pendispersi Lumpur

7. Padatan tersuspensi dalam air akan menjadi gumpalan (flocs) akibat aktivitas mikroorganisme dan terakumulasi sebagai lumpur. Pengolahan dispersi lumpur bukan hanya meredam pembentukan gumpalan tetapi juga mendispersi gumpalan yang telah terbentuk. Padatan tersuspensi yang terdispesi dibuang keluar melalui air blowdown sehingga volume akumulasi lumpur dikurangi. Bahan kimia untuk pencegahan pelekatan lumut dan pengikisan lumut juga digunakan untuk pendispersi lumut dan untuk bioflokulasi (penggumpalan akibat mikrobiologi) padatan tersuspensi. Juga polielektrolit atau polimer digunakan untuk pendispersi anorganik padatan tersuspensi atau peredaman penggumpalan padatan tersuspensi.

8. Penyaringan pembantu.

9. Ini adalah suatu pengolahan untuk menurunkan akumulasi lumpur dan pelekatan lumut yaitu dengan jalan penyaringan sebagian air pendingin yang disirkulasikan untuk membuang padatan tersuspensi

\section{TATA KERJA}

\section{Peralatan dan Bahan}

1. Botol sampel

2. Gelas erlemeyer

3. Tisu

4. Dipslides Test 
5. Inhibitor bioksida pengoksidasi

\section{Prosedur Kerja}

1. Sampel air pendingin sekunder diambil pada 2 tempat pengambilan yaitu pada kolam menara pendingin (lokasi 1)dan pipa(lokasi2)

2. Jumlah total bakteri ditentukan dengan menggunakan Dipslide Test dengan langkah sebagai berikut ${ }^{[5]}$ :

3. Dibuka tabung dan keluarkan slide Envirocheck tanpa menyentuh permukaan agarnya

4. Slide Envirocheck Dicelupkan kedalam sampel air pendingin sekunder hingga permukaan agarnya bener-benar basah dan diamkan slide Envirocheck kontak dengan sampel air pendingin sekunder sekitar 5-10 detik.

5. Sudut bagian bawah slide dikeringkan dengan kertas penyerap( tisu)

6. Dimasukan kembali slide ke tabungnya dan dilakukan inkubasi selama 2 hari

7. Setelah inkubasi selama 2 hari dibandingkan density dari koloni yang berkembang di media agar dengan model density chart sehingga diketahui jumlah total bakteri.

\section{HASIL DAN PEMBAHASAN}

Pemantauan pertumbuhan mikroorganisme pada air pendingin sekunder dilakukan dengan melihat jumlah total bakteri menggunakan dipslides test dan hasilnya ditampilkan pada Tabel 1. Dari Tabel 1 terlihat bahwa jumlah total bakteri pada air pendingin sekunder secara keseluruhan masih di bawah batas yang dipersyaratkan dimana batasan adalah $10^{6}$ ini menunjukan bahwa pertumbuhan mikroorganisme pada sistem pendingin sekunder masih terkendali. Tetapi apabila dilihat secara rinci dari Tabel 1 terlihat bahwa pada saat sistem pendingin sekunder shutdown seperti terlihat data pada tanggal 30 April 2009 dan 14 mei 2009 menunjukan bahwa jumlah total bakteri pada air pendingn sekunder besar, ini berarti bahwa pada saat sistem pendingin sekunder tidak beropersi pertumbuhan mikroorganisme pesat. Hal ini disebabkan karena selama sistem pendingin sekunder tidak beroperasi, tidak dilakukan penambahan bioksida pengoksidasi pernyataan ini diperkuat dengan adanya data pada tanggal 8 Mei 2009 dimana sistem sudah beroperasi tetapi belum dilakukan penambahan bioksida pengoksidasi. Bioksida pengoksidasi merupakan bahan kimia bersifat oksidator yang berfungsi untuk menghilangkan pertumbuhan mikroorganisme. Bahan kimia ini akan membunuh mikroorganisme dengan daya oksidasinya. Oleh karena itu 
setelah penambahan bioksida pengoksidasi pada sistem pendingin sekunder pertumbuhan mikroorganisme pada air sistem pendingin sekunder menurun

Tabel 1. Hasil Pemantauan Pertumbuhan Mikroorganisme Pada Air Pendingin Sekunder

\begin{tabular}{|c|c|c|c|c|}
\hline No & Tanggal / Hari & Total Bakteri & Gambar & Keterangan \\
\hline I.A & $\begin{array}{l}28 \text { April '09 } \\
\text { (Selasa) }\end{array}$ & $<10^{3}$ & 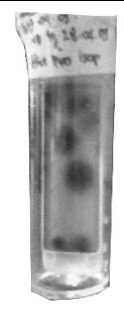 & $\begin{array}{l}\text { - Sistem pendingin beroperasi } \\
\text { - Penambahan Oxidizing } \\
\text { Biocides (Bioksida Pengoksidasi) } \\
\text { dilakukan SeninTgl } 27 \text { April '09 } \\
\text { - Sampel diambil setelah } \\
\text { penambahan } \\
\text { - Sampel diambil dari kolam } \\
\text { menara pendingin(Lokasi 1) }\end{array}$ \\
\hline I.B & $\begin{array}{l}28 \text { April '09 } \\
\text { (Selasa) }\end{array}$ & $<10^{3}$ & & $\begin{array}{l}\text { Sampel diambil dari pipa } \\
\text { (Lokasi 2) }\end{array}$ \\
\hline II & $\begin{array}{l}30 \text { April '09 } \\
\text { (Kamis) }\end{array}$ & $<10^{5}$ & & $\begin{array}{l}\text { - Sistem Pendingin Shut Down } \\
\text { - sampel diambil dari kolam } \\
\text { menara pendingin(Lokasi 1) }\end{array}$ \\
\hline III & $\begin{array}{l}8 \text { Mei '09 } \\
\text { (Jum'at) }\end{array}$ & $<105$ & & $\begin{array}{l}\text { - Sampel diambil dari kolam } \\
\text { menara pendingin(Lokasi 1) } \\
\text {-Sistem Pendingin Beroperasi } \\
\text { (awal operasi setelah shutdown } \\
\text { dari } 29 \text { April s/d } 7 \text { Mei’09) } \\
\text {-Sample diambil sebelum Sistem } \\
\text { ditambah Oxidizing Biocides } \\
\text { (Bioksida Pengoksidasi) }\end{array}$ \\
\hline IV & $\begin{array}{l}11 \text { Mei '09 } \\
\text { (Senin) }\end{array}$ & $<104$ & & $\begin{array}{l}\text { - sampel diambil dari kolam } \\
\text { menara pendingin(Lokasi 1) } \\
\text { - Sistem Pendingin Beroperasi } \\
\text {-Penambah Oxidizing Biocides } \\
\text { (Bioksida } \\
\text { Pengoksidasi)dilakukan Jum'at } 8 \\
\text { Mei'09 sore }\end{array}$ \\
\hline
\end{tabular}


Tabel 1. Hasil Pemantauan Pertumbuhan Mikroorganisme Pada Air Pendingin Sekunder (lanjutan)

\begin{tabular}{|c|c|c|c|c|}
\hline No & Tanggal/hari & Total bakteri & Gambar & Ketrangan \\
\hline V & $\begin{array}{l}12 \text { Mei '09 } \\
\text { (Selasa) }\end{array}$ & $<10^{3}$ & & $\begin{array}{l}\text { - Sistem Pendingin Beroperasi } \\
\text { - Penambahan Oxidizing } \\
\text { Biocides (Bioksida Pengoksidasi) } \\
\text { dilakukan Senin } 11 \text { Mei'09 }\end{array}$ \\
\hline VI & $\begin{array}{l}14 \text { Mei '09 } \\
\text { (Kamis) }\end{array}$ & $<10^{5}$ & & $\begin{array}{l}\text { - sampel diambil dari kolam } \\
\text { menara pendingin(Lokasi 1) } \\
\text { - Sistem Pendingin Shut Down } \\
\text { Penambahan Oxidizing Biocides } \\
\text { (Bioksida } \\
\text { Pengoksidasi)dilakukan Senin } 11 \\
\text { Mei’09 }\end{array}$ \\
\hline VII & $\begin{array}{l}18 \text { Mei '09 } \\
\text { (Senin) }\end{array}$ & $<10^{4}$ & & $\begin{array}{l}\text { - sampel diambil dari kolam } \\
\text { menara pendingin(Lokasi 1) } \\
\text {-Sistem Pendingin Beroperasi } \\
\text { (awal operasi Jum'at } 15 \text { Mei'09 } \\
\text { setelah shutdown dari } 13 \text { s/d } 14 \\
\text { Mei'09) } \\
\text {-Penambahan Oxidizing } \\
\text { Biocides (Bioksida } \\
\text { Pengoksidasi)Jum'at } 15 \text { Mei '09 } \\
\text { sore }\end{array}$ \\
\hline VIII & $\begin{array}{l}19 \text { Mei '09 } \\
\text { (Selasa) }\end{array}$ & $\begin{array}{l}<10^{3} \\
2 \text { Titik }\end{array}$ & & $\begin{array}{l}\text { - Sistem Pendingin Beroperasi } \\
\text { - Penambahan Oxidizing } \\
\text { Biocides (Bioksida engoksidasi) } \\
\text { dilakukan Senin } 18 \text { Mei'09 pagi }\end{array}$ \\
\hline
\end{tabular}

seperti terlihat pada data hari Selasa tanggal 28 Apri 2009, 12 Mei 2009 dan 19Mei 2009 dimana jumlah total bakteri yang terdeteksi pada tanggal tersebut mengalami penurunan an akan mengalami kenaikan pada hari berikutnya seperti terlihat pada data tanggal 11 dan 18 Mei 2009. Hal ini disebabkan karena pada hari Senin tanggal 27 Apri 2009,11 Mei 2009 dan 18 Mei 2009 telah dilakukan penambahan bioksida pengoksidasi. Sedangkan data tanggal 
11 dan 18 Mei 2009 penambahan bioksida pengoksidasi dilakukan hari Jum,at sore tanggal 8 Mei 2009 dan 15 Mei 2009.dimana merupakan awal dari pengoperasian sistem pendingin sekunder. Penambahan bioksida pengoksidasi akan menyebabkan kenaikan kandungan klorin pada air sistem pendingin sekunder seperti terlihat pada Tabel 2.

Dari Tabel 2 terlihat bahwa setelah penambahan bioksida pengoksidasi kandungan klorin dalam air pendingin sekunder baik dalam bentuk klorin aktif, klorin bebas maupun klorin terikat meningkat sangat tajam. Hal ini dikarenakan bioksida pengoksidasi merupakan sumber klorin untuk membunuh mikroorganisme dalam sistem pendingin sekunder RSG-GAS. Kemudian menurun pada hari berikutnya. Ini mengindikasikan adanya klorin yang berikatan dengan mikroorganisme dan secara aktif menghilangkan mikroorganisme tersebut. Dengan demikian pertumbuhan mikroorganisme akan mengalami pengurangan setelah penambahan bioksida pengoksidasi pada sistem

Pendingin sekunder dan akan mengalami kenaikan pada hari berikutnya. Dari Tabel 1 terlihat juga bahwa data tanggal 28 April 2009 dimana jumlah total bakteri pada sample IA lebih kecil dari sample IB. Hal ini disebabkan karena pengambilan sampel dilakukan dari tempat yang berbeda dimana sample IA diambil dari kolam menara pendingin (Lokasi 1)dan sampel IB diambil dari pipa(Lokasi 2) sedangkan penambahan bioksida pengoksidasi dilakukan pada kolam. Lokasi pengambilan sampel ditunjukan pada Gambar 1. Oleh karena itu kandungan bioksida pengoksidasi setelah melewati pipa akan mengalami pengurangan yang mengakibatkan jumlah total bakteri pada sample air yang diambil dari pipa akan lebih besar.

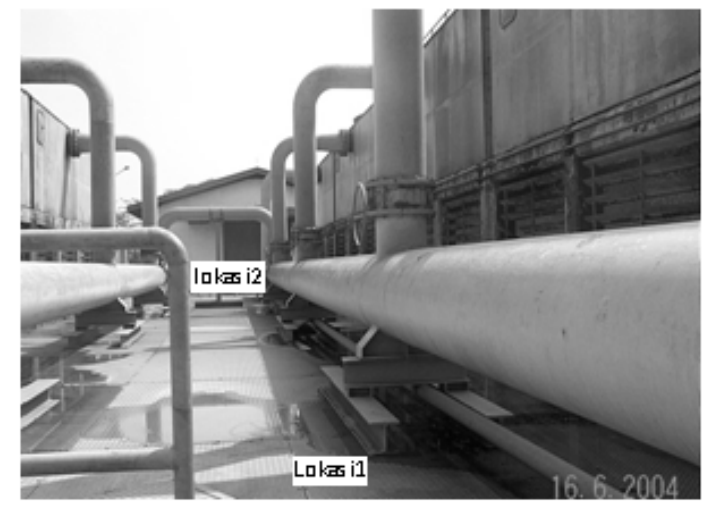

Gambar 1. Lokasi pengambilan sampel air pendingin sekunder 
Tabel 2: Hasil pengukuran kandungan klorin dalam air pendingin sekunder sebelum dan sesudah sistem pendingin ditambah inhibitor bioksida pengoksidasi ${ }^{[7]}$

\begin{tabular}{|c|c|c|c|c|}
\hline $\begin{array}{l}\text { Waktu } \\
\text { (hari) }\end{array}$ & $\begin{array}{c}\text { Klorin } \\
\text { Aktif } \\
(\mathrm{ppm})\end{array}$ & $\begin{array}{l}\text { Klorin } \\
\text { Bebas } \\
(\mathrm{ppm})\end{array}$ & $\begin{array}{l}\text { Klorin } \\
\text { Terikat } \\
(\mathrm{ppm})\end{array}$ & Keterangan \\
\hline 27-Jan-08 & 0.04 & 0.015 & 0.025 & $\begin{array}{l}\text { Sebelum penambahan bioksida } \\
\text { pengoksidasi }\end{array}$ \\
\hline 28-Jan-08 & 0.223 & 0.06 & 0.163 & $\begin{array}{l}\text { Penambahan bioksida } \\
\text { pengoksidasi }\end{array}$ \\
\hline 29-Jan-08 & 0.042 & 0.023 & 0.018 & $\begin{array}{l}\text { Sehari setelah penambahan } \\
\text { bioksida engoksidasi }\end{array}$ \\
\hline 30-Jan-08 & 0.033 & 0.015 & 0.017 & $\begin{array}{l}\text { Sebelum penambahan bioksida } \\
\text { pengoksidasi }\end{array}$ \\
\hline 1-Feb-08 & 0.146 & 0.022 & 0.123 & $\begin{array}{l}\text { Penambahan bioksida } \\
\text { pengoksidasi }\end{array}$ \\
\hline 3-Feb-08 & 0.048 & 0.019 & 0.029 & $\begin{array}{l}\text { Sebelum penambahan bioksida } \\
\text { pengoksidasi }\end{array}$ \\
\hline 4-Feb-08 & 0.141 & 0.032 & 0.109 & $\begin{array}{l}\text { Penambahan bioksida } \\
\text { pengoksidasi }\end{array}$ \\
\hline 5-Feb-08 & 0.05 & 0.027 & 0.023 & $\begin{array}{l}\text { Sehari setelah penambahan } \\
\text { ioksidapengoksidasi }\end{array}$ \\
\hline 6-Feb-08 & 0.046 & 0.023 & 0.022 & $\begin{array}{l}\text { Dua hari setelah penambahan } \\
\text { bioksida pengoksidasi }\end{array}$ \\
\hline 7-Feb-08 & 0.042 & 0.022 & 0.02 & $\begin{array}{l}\text { Sebelum penambahan bioksida } \\
\text { pengoksidasi }\end{array}$ \\
\hline 8-Feb-08 & 0.182 & 0.034 & 0.148 & $\begin{array}{l}\text { Penambahan bioksida } \\
\text { pengoksidasi }\end{array}$ \\
\hline 10-Feb-08 & 0.04 & 0.012 & 0.028 & $\begin{array}{l}\text { Sebelum penambahan bioksida } \\
\text { pengoksidasi }\end{array}$ \\
\hline 11-Feb-08 & 0.201 & 0.04 & 0.161 & $\begin{array}{l}\text { Penambahan bioksida } \\
\text { pengoksidasi }\end{array}$ \\
\hline 12-Feb-08 & 0.074 & 0.024 & 0.05 & $\begin{array}{l}\text { Sehari setelah penambahan } \\
\text { bioksida pengoksidasi }\end{array}$ \\
\hline 17-Feb-08 & 0.071 & 0.018 & 0.053 & $\begin{array}{l}\text { Sebelum penambahan bioksida } \\
\text { pengoksidasi }\end{array}$ \\
\hline 18-Feb-08 & 0.211 & 0.036 & 0.175 & $\begin{array}{l}\text { Penambahan bioksida } \\
\text { pengoksidasi }\end{array}$ \\
\hline 19-Feb-08 & 0.077 & 0.023 & 0.054 & $\begin{array}{l}\text { Sebelum penambahan bioksida } \\
\text { pengoksidasi }\end{array}$ \\
\hline 20-Feb-08 & 0.177 & 0.038 & 0.139 & $\begin{array}{l}\text { Penambahan bioksida } \\
\text { pengoksidasi }\end{array}$ \\
\hline 21-Feb-08 & 0.07 & 0.032 & 0.038 & $\begin{array}{l}\text { Pengamatan setelah penambahan } \\
\text { bioksida pengoksidasi }\end{array}$ \\
\hline
\end{tabular}

KESIMPULAN

Dari dari uraian di atas dapat disimpulkan bahwa pertumbuhan mikroorganisme pada air pendingin sekunder lebih cepat pertumbuhannya pada saat sistem pendingin sekunder tidak beroperasi dan akan mengalami penurunan pertumbuhannya setelah penambahan bioksida pengoksidasi yang 
mengindikasikan adanya klorin yang bereaksi dengan mikroorganisme dan secara aktif menghilangkan mikroorganisme tersebut.

\section{DAFTAR PUSTAKA}

1. KEMMER,F N, 1988, The NALCO Water Handbook, 2 ed, Mc.Grow Hill Book Company.

2. ANONIM, "Peran Mikrooganisme Dalam Kehidupan", diakses melalui http://id. Wikipedia.org/wiki/mikroorganisme.

3. DARKUNI, M. NOVIAR, 2001, Mikrobiologi (Bakteriologi, Virologi, dan Mikologi). Malang: Universitas Negeri Malang.

4. ANONIM, Handbook of Water Treatment, Cooling Tower, Kurita.

5. ANONIM, Instructions For Use Envirocheck Contact, Merck.

6. CHATTORAJ, et al, 2003, "Demand-Based, Real Time Control of Microbial Growth in Air-Conditioning Cooling Water Systems", Volume 109, Part 1, American Society of Heating, Refrigerating and Air Conditioning Engineers, inc., USA.

7. DIYAH ERLINA LESTARI, 2008, "Pengaruh Penambahan Biokdsida Pengoksidasi terhadap Kandungan Klorin untuk Pengendalian Pertumbuhan Mikroorganisme pada Air Pendingin Sekunder RSG-GAS”, Seminar Nasional IV SDM Teknologi Nuklir, Yogyakarta. 